\title{
REGIONAL VARIABLES THAT INFLUENCE THE ALLOCATION OF VENTURE CAPITAL: THE ROLE OF BANKS*
}

\author{
Glen C. Pulver and Ronald J. Hustedde**
}

Growing public recognition of the importance of business start-ups and expansion in the generation of employment and creation of wealth has stimulated the interest of policymakers in the adequacy of equity capital markets. Investments in previously unknown technology and/or businesses providing limited physical collateral often are viewed as especially high risk and thus, difficult to finance. When this situation is compounded by the lack of substantial ownership equity or collateral, debt capital seldom is available. These investments usually require equity commitment by family, friends, or venture capitalists.

A growing percentage of new jobs is found in those industries utilizing high technology and in the serviceproducing sectors with few tangible physical assets (Pulver, 1986). Business start-ups continue to depend largely on funding from family and friends (Combs, Shaffer, and Pulver, 1983). Early stage development and expansions of those firms requiring large amounts of capital and with high growth potential are candidates for venture capital providers. The economic development of specific regions, therefore, is increasingly dependent upon how well venture capital markets function.

The venture capital industry tends to concentrate its investments in certain geographic areas. Some states receive little venture capital while others are far above the national average. Table 1 summarizes regional distributions of venture capital during 1985.

The states of California, Texas, and Massachusetts attracted 63 percent of venture capital disbursements (Morris, May 1986). These variations in disbursements have generated concern among regional-oriented policymakers and economic developers about regional unevenness of equity capital investment. These differences may be due to variables that are unique to specific regions. A critical question raised by public policymakers is, "Why do some states/regions of the United States receive less venture capital than others?"

\footnotetext{
*The research on which this article is based was funded by the United States Department of Agriculture and the College of Agriculture and Life Sciences, University of Wisconsin-Madison.

**The authors are, respectively, professor and research assistant in the Department of Agricultural Economics at the University of Wisconsin-Madison.
}

The major focus of this paper is to examine the regional variables that have the strongest influence on the allocation of venture capital with special emphasis on the information role of banks. The paper is divided into five sections: (1) a description of venture capital markets, (2) a summary of the factors that venture capitalists perceive as important in market transactions, (3) an analysis of bankers' involvement in venture capital markets, (4) some general conclusions, and (5) policy recommendations.

Venture capital is defined as equity or "risk" money that is invested in relatively new or expanding firms which promise high growth rates and investment return (Premus, 1985). Venture capital (a type of equity capital) contrasts sharply with debt or loan capital which is one of the most common forms of funding for small business. Equity investors seek ownership rights within the firms in which they invest. Debt capital suppliers such as banks usually require collateral as protection in the event the investment should fail. Equity suppliers, on the other hand, do not have such assurances. Hence, equity capital suppliers are subject to greater risk.

For purposes of this paper, venture capital is more narrowly defined as a minimum of $\$ 100,000$ of equity monies that generally are used for research and development, firm start-ups, and firm expansion. The paper is concerned with the organized venture capital industry, not with informal investors or "angels," even though they play a significant role in research and development, and start-up phases.

\section{Description of Venture Capital Markets}

The organized venture capital industry tends to invest in firms in which the industry holds 25 percent or more of ownership rights in the form of preferred or common stock or convertible debentures. Venture capitalists commonly spread their investment over a number of firms, expecting some to succeed and others to fail. In contrast to most bankers, venture capitalists are not passive investors. They often sit on the boards of directors and work actively with the management of the firms in which they invest. Venture capitalists frequently maintain active roles for five or six years hoping that the firms will be so successful that the stock value of their most successful ventures will be worth 10 to 20 times the original investment. Eventually, 
Table 1

1985 Venture Capital Disbursements, by Region

\begin{tabular}{lc}
\hline \hline Region & $\begin{array}{c}\text { Amount Invested } \\
\text { (percent) }\end{array}$ \\
\hline Northeast (Conn., Mass., Maine, N.H., N.J., N.Y., R.I., Vt.) & 22 \\
Mid-Atlantic (D.C., Del., Md., Pa., Va., W.Va.) & 5 \\
Southeast (Ala., Fla., Ga., Ky., Miss., N.C., S.C., Tenn.) & 4 \\
Midwest/Plains (lowa, Ill., Ind., Kan., Mich., Minn., Mo., Nev., Ohio, S.D., Wis.) & 8 \\
Southwest/Rockies (Ariz., Colo., Idaho, La., Mont., N.M., Okla., Texas, Utah) & 13 \\
West Coast (Calif., Ore., Wash.) & 48 \\
& 100 \\
\hline \hline
\end{tabular}

Source: Morris, May 1986.

venture capitalists sell their ownership rights to management, to other firms, or through public securities. Venture capitalists hope to average a 25 to 40 percent compounded annual return on their investment portfolios over a five or six year time frame. Because few investment opportunities promise returns at this level, venture capitalists provide a relatively small percentage of the total capital investment in the private sector (Silver, 1982; Dominguez, 1974).

Nationally, venture capital disbursements increased from one billion dollars in 1979 to 2.6 billion dollars in 1985 (Morris, ed., May 1986). This underscores the growing demand for this kind of investment. It also suggests that more investors may perceive the venture capital industry as credible and lucrative in spite of the financial risk involved.

The venture capital community can be classified into four major groups:

1. Small Business Investment Companies. These use funds from the Small Business Administration to leverage investments from private sources. Many banks have formed their own SBICs in recent years;

2. Independent Private Venture Capital Firms. These may be partnerships or individuals who have raised monies from pension funds, wealthy individuals, or families and other sources;

3. Corporate Venture Capital Subsidiaries. In recent years, several major corporations have developed venture subsidiaries as mechanisms for widening their investment portfolios and to control the development of new technology; and
4. Public or Quasi-Public Venture Capital Funds. Some states, cities and regional economic associations have used pension funds or public monies to make direct capital investments. These public and quasi-public organizations usually are exclusively committed to economic growth within particular geographic areas (Silver, 1985; Greene, 1985)

In 1985, 36 percent of United States venture monies were invested in firm start-ups or other early stage aspects. Fifty-four percent of funds were directed toward firm expansion. Only 10 percent of funds were distributed for leveraged buy-outs, acquisitions and other purposes (Venture Capital Journal, May 1986). That venture capital investments are scattered over a wide range of industries is evidenced by the information in Table 2 .

Computer hardware and systems accounted for the largest portion of dollars invested in 1984 and 1985 . There was a drop from 29 percent in 1984 to 25 percent in 1985 that might be explained by the downswing in public stocks for computer hardware and systems and the problems experienced by several computer firms in the past few years.

Telephone and data communications investments were concentrated in local area networks, communications processors, network management, and telephone management systems. Medical and health related business financing runs the gamut from products such as anaesthetic lollipops for children to pharmaceuticals, hospital equipment, and HMO and health care facilities.

Close observers of the venture capital industry have asserted that there is an emerging interest in consumerrelated companies, an area that generally has been avoided. 
Table 2

1985 Venture Capital Disbursements by Industry Category in the U.S.

\begin{tabular}{lr}
\hline \hline & $\begin{array}{c}\text { Industry Category } \\
\text { Commercial Communications } \\
\text { Telephone and Data Communications }\end{array}$ \\
\hline Computer Hardware and Systems & 12 \\
Software and Services & 25 \\
Other Electronics & 10 \\
Genetic Engineering & 14 \\
Medical/Health Care-related & 5 \\
Energy-related & 10 \\
Industry Automation & 1 \\
Industrial Products and Machinery & 4 \\
Consumer-related & 2 \\
Other Products and Services & 7 \\
& $\frac{6}{100}$ \\
\hline \hline
\end{tabular}

Source: Morris, ed., May 1986.

Consumer-oriented firms that have attracted attention include book stores, discount software, greetings cards, dress shops, creative gifts, specialty golf clubs, marine accessories, and specialty restaurants. It was anticipated that there would be an increase in such investments in 1987 (New York Times, February 6, 1987).

\section{Factors Affecting Venture Capital Investment}

Theory suggests a series of market variables that might act as barriers to capital allocation in specific geographic areas. These variables include inter-area differences in business and personal taxes, securities and other regulations, market information, labor availability and quality, and public and private attitudes toward business financing (Mikesell and Davidson, 1982).

Forty venture capitalists from Illinois, Iowa, Michigan, Minnesota, and Wisconsin were interviewed in 1985. These capitalists represented most of the major venture investors in the upper Midwest (Pratt 1984). They were asked to rate state features, other than the quality of specific deals, that were most important in determining the geographic distribution of their investments. Ratings were in four categories: (1) very important, (2) somewhat important, (3) of minor importance, and (4) not important. Table 3 indicates the importance they attached to these selected factors.

In the view of the venture capitalists, four of the six factors most important in determining the regional allocation of venture capital investments are information variables (Table 3). The knowledge of bankers, accountants, and attorneys of venture capital tied for first in the rankings. The activity of schools and colleges in developing opportunities for investment and the availability of skilled labor tied for third. The preparation of venture proposals was ranked fifth and the knowledge of business people was sixth. All have a clear linkage to education and knowledge.

Over 94 percent of the venture capitalists viewed the knowledge of venture capital markets of bankers, accountants, and attorneys as a very important or somewhat important factor in influencing venture capital investment decisions in a state. These three groups of professionals play critical roles in linking venture capitalists with entrepreneurs. Venture capitalists almost uniformly cited bankers, accountants, and attorneys as key informants. Several venture capitalists offered anecdotal evidence to illustrate this importance. For example, one venture capitalist said he had never funded anyone who was not first introduced to him by a banker, accountant, or attorney. Recommendations from these individuals often can serve as a screening device to distinguish the potentially more lucrative deals from those with little promise. Many venture capitalists have developed informal information networks in which the opinions of trusted bankers, accountants and attorneys are highly valued.

The knowledge of business people about venture 
Table 3

Perceptions of Venture Capitalists Regarding Importance of Various Factors in Venture Capital Investment Decisions

\begin{tabular}{|c|c|c|}
\hline & Factor & $\begin{array}{l}\text { Percentage Responding } \\
\text { "Very Important" or } \\
\text { "Somewhat Important" }\end{array}$ \\
\hline & \multicolumn{2}{|l|}{ Taxes } \\
\hline & Capital Gains Taxes & 69 \\
\hline & Personal Income Taxes & 61 \\
\hline & Corporate Taxes & 56 \\
\hline & Property Taxes & 39 \\
\hline & Inheritance Taxes & 14 \\
\hline & \multicolumn{2}{|l|}{ Regulations } \\
\hline & State Securities Regulations & 81 \\
\hline & Environmental Regulations & 36 \\
\hline & Land Zoning Regulations & 19 \\
\hline & \multicolumn{2}{|l|}{ Information } \\
\hline & Bankers' Knowledge of Venture Capital & 94 \\
\hline & Accountants' and Attomeys' Knowledge of Venture Capital & 94 \\
\hline & Business People's Knowledge of Venture Capital & 83 \\
\hline & Preparation of Venture Proposals & 86 \\
\hline & Venture Fairs & 50 \\
\hline \multirow[t]{10}{*}{$\cdot$} & \multicolumn{2}{|l|}{ Labor } \\
\hline & Available Skilled Labor & 92 \\
\hline & Price of Skilled Labor & 78 \\
\hline & \multicolumn{2}{|l|}{ Attitudes } \\
\hline & Communities Seek Back-up Financing & 64 \\
\hline & Local Government Cooperation & 53 \\
\hline & Local Development Organizations & 64 \\
\hline & Utilities Representatives' Assistance & 19 \\
\hline & State Govemment Agencies' Helpfulness & 58 \\
\hline & Schools and Colleges Active in Developing Opportunities & 92 \\
\hline
\end{tabular}

Source: Hustedde, 1987.

capital was viewed either as very or somewhat important by 83 percent of venture capitalists. If entrepreneurs are unaware of venture capital markets, they are unlikely to seek venture capital.

The level or quality of preparation of venture capital proposals was thought to be very important or somewhat important by 86 percent of those venture capitalists who were interviewed. These proposals introduce the business plans of entrepreneurs to the venture capitalists and serve as a useful tool for triggering further discussions. Accountants, bankers, and attorneys also provide useful assistance in developing business plans. The Small Business Administration, university-related business services, and other agencies and groups also assist entrepreneurs.

Venture fairs can link entrepreneurs with potential investors. However, only 50 percent of the capitalists viewed these fairs as very or somewhat important. Several venture capitalists indicated that they are aware of most opportunities in their areas before they are presented at venture fairs. They viewed venture fairs as a common ground on which to meet other investors, particularly local investors.

The information issue was explored further in an open-ended question: "What are your sources of information about investment opportunities?" Venture capitalists listed several sources. Seventy-two percent listed profes- 
sional advisors such as accountants, attorneys and bankers. Sixty-six percent claimed other venture capitalists were important information sources. Capitalists also learned about investment opportunities from the investment banking community, unsolicited walk-ins, current and past portfolio companies, trade and venture fairs, support groups (such as the Small Business Administration), professional consultants and affiliates in other parts of the venture firm, and several other sources.

When asked "Where do those individuals who need venture capital get information about venture capital? ," 83 percent of the capitalists replied that accountants, attorneys, and bankers were the most likely sources of information. Fifty-two percent cited professional venture magazines, trade journals, books and other periodicals. Several capitalists pointed to the increased coverage of venture capital by the popular national press as beneficial in stimulating awareness.

When asked for brochures about their firms, many venture capitalists did not have one. None of them indicated that they conducted advertising programs, but a few had done promotional work through public speaking engagements. Venture capitalists operate by "word-ofmouth" primarily through bankers, accountants, attorneys, and the cooperation of other venture capitalists.

\section{Involvement of Bankers in Venture Capital Markets}

Clearly, the knowledge of bankers about venture capital markets is very important in the geographic distribution of venture capital. They can play critical roles in advising entrepreneurs where equity capital may be acquired and in acquainting venture capitalists with prospective deals.

In order to gain greater understanding of the knowledge of bankers of these markets, all banks in Minnesota and Wisconsin with over \$24 million in assets were surveyed by mail. Responses were received from 161 of 320 banks. (Twenty-four million dollars is an artificial cut-off point chosen because of data availability.) It was assumed that those banks with assets of more than \$24 million would be more likely to be involved in larger and more complex business deals than those with fewer assets and, thus, would have more reason to be knowledgeable about venture capital markets.

The states of Wisconsin and Minnesota were chosen because of their many similarities in population, economic base, geography and the wide variation in venture capital allocation between the two. Wisconsin received venture capital placements in 1984 of approximately $\$ 3.67$ per capita while Minnesota received $\$ 21.62$ per capita. The 1984 national average was \$12.71 per capita (Wade and
Place, 1985). Some of the differences may be due to the availability of "good deals" or to such factors as industrial mix or the general entrepreneurial environment.

The combined responses of the banks in the two states were hypothesized to exhibit wide variations in awareness of, and referrals to, potential equity investors. Variations were expected due to the rural-urban location of the bank, bank asset level, and bank type. It was expected that the banks which are least knowledgeable and less active in venture markets would be those in rural areas, with fewer assets, and with limited involvement in commercial and industrial loans. Logit and order of least square estimates were used to test for significance of differences in responses.

\section{Rural-Urban Influence}

Analysis of the data supports the hypothesis that nonmetropolitan banks are less involved in venture capital markets than their metropolitan counterparts. Table 4 indicates that less than half of the non-metropolitan banks were approached by clients seeking $\$ 100,000$ or more of equity capital. On the surface, it may appear that the demand for equity capital is quite limited in these areas. However, a more serious and hidden information gap may be indicated. Business people in these regions may not be aware of financing options such as equity investments. They may look to their local bankers for such information, but unaware or financially conservative bankers may contribute to the information gap because they believe their specialty is debt capital and hence are reluctant to assist their clients with equity financing. They also may be unaware of the complimentary nature of debt and equity financing.

Almost two-thirds of the metropolitan banks had clients seeking $\$ 100,000$ or more of equity capital. Less than half of the non-metropolitan banks had such requests. This finding supports the hypothesis that there is more venture activity in metropolitan areas. Further research may indicate that non-metropolitan seekers of venture financing look outside their regions to seek the assistance of metropolitan bankers.

Seventy-seven percent of the metropolitan banks were familiar with equity investors, yet only 44 percent of their non-metropolitan counterparts knew of such individuals.

When actual client referrals to equity investors were examined, the rural-urban dichotomy appeared even stronger. Only 29 percent of non-metropolitan banks made such referrals, whereas 70 percent of the urban banks linked clients with potential equity investors. Under such conditions, it can be concluded that non-metropolitan 
Table 4

Bank Involvement in Venture Capital Markets, by Geographic Location

\begin{tabular}{cccc}
\hline \hline & $\begin{array}{c}\text { Clients Contacted } \\
\text { Banks for Help to } \\
\text { Locate Equity Monies } \\
\text { (percent) }\end{array}$ & $\begin{array}{c}\text { Banks Aware } \\
\text { of Potential } \\
\text { (percent) }\end{array}$ & $\begin{array}{c}\text { Banks Referred } \\
\text { Clients to } \\
\text { Equity Investors } \\
\text { (percent) }\end{array}$ \\
\hline Metropolitan Banks* & $\begin{array}{c}66 \\
\mathrm{~N}=24\end{array}$ & $\begin{array}{c}77 \\
\mathrm{~N}=27\end{array}$ & $\begin{array}{c}70 \\
\mathrm{~N}=27\end{array}$ \\
Non-metropolitan Banks & $\begin{array}{c}47 \\
\mathrm{~N}=134\end{array}$ & $\mathbf{N}=134$ & $\mathbf{N}=127$ \\
\hline \hline
\end{tabular}

*Banks in Minneapolis, St. Paul, Milwaukee, and Madison metropolitan areas.

$\mathbf{N}=$ number of total usable responses in each cell

entrepreneurs find it difficult to achieve the kind of business growth that their urban counterparts can achieve.

\section{Influence of Bank Size}

It also was hypothesized that banks with larger assets are more aware of equity investors and take an active part in linking their clients with equity suppliers. It was reasoned that banks with more resources have the capacity to hire individuals who are specialized in business and sensitive to business needs. The fact that the banks are large also suggests that they serve larger geographic areas, have diversified clienteles, and, hence, have more sophisticated connections with all aspects of business. If the banks are larger, individuals seeking equity capital will be more likely to contact them.

The information in Table 5 supports the suggested hypothesis. That is, as bank assets increase, banks tend to receive more requests from people who want assistance in seeking equity capital. Furthermore, the table indicates that banks in larger asset categories have greater awareness of potential equity suppliers. Banks with more assets refer more clients to equity or venture investors.

Thirty-three percent of the banks in the smallest asset category received requests from clients for assistance in seeking equity monies, whereas 71 percent of the banks with assets of $\$ 200$ million or more reported that clients contacted them for help in locating equity capital. Although the differences in percentages appears large, statistical tests did not find it significant.

Table 5 indicates that banks in the larger asset categories were more knowledgeable about potential equity capital investors $(\$ 100,000$ or more). For example, only 31 percent of the respondents from banks with less than $\$ 50$ million in assets knew of individuals who could invest at least $\$ 100,000$ in equity capital. However, 88 percent of the banks with assets of $\$ 200$ million or more indicated that they were aware of potential equity suppliers.

The pattern was even more pronounced for client referrals to equity investors. Only 8 percent of the banks in the smallest asset category made such referrals, whereas, 88 percent of those with assets of $\$ 200$ million or more linked equity investors with their clients. Diffferences in both knowledge of equity sources and in referrals were statistically significant.

\section{Influence of Bank Type}

It was hypothesized that banks with higher portions of their assets invested in commercial and industrial loans also would be more actively involved in venture capital markets than those with lower percentages. Banks most involved in commercial and industrial loans can be viewed as specialists in business investment and therefore, more effective in linking investors and seekers of equity capital. It was expected that clients would view banks with higher percentages of assets in business loans as more knowledgeable about business. Thus, these banks would be more likely to be contacted by individuals and groups seeking equity capital.

The data in Table 6 suggest that banks with higher percentages of commercial and industrial loans received more requests for help in locating equity monies. Only 36 percent of those banks which had less than 10 percent of their assets in business loans received equity assistance requests from their clients. In contrast, 69 percent of the banks with 20 percent or more of their assets in commercial and industrial loans indicated that they had clients contact them for assistance in locating equity monies.

Table 6 also suggests that the banks with higher 
Table 5

Reponses from Banks Regarding Equity Capital Markets, by Asset Level

\begin{tabular}{|c|c|c|c|}
\hline $\begin{array}{l}\text { Bank Assets } \\
\text { (dollars) }\end{array}$ & $\begin{array}{l}\text { Clients Contacted } \\
\text { Banks for Help to } \\
\text { Locate Equity Monies* } \\
\text { (percent) }\end{array}$ & $\begin{array}{l}\text { Banks Aware } \\
\text { of Potential } \\
\text { Equity Investors* } \\
\text { (percent) }\end{array}$ & $\begin{array}{l}\text { Banks Referred } \\
\text { Clients to } \\
\text { Equity Investors* } \\
\text { (percent) }\end{array}$ \\
\hline 22 million to 49.999 million & $\begin{array}{c}33 \\
N=63\end{array}$ & $\begin{array}{c}31 \\
N=61\end{array}$ & $\begin{array}{c}8 \\
N=62\end{array}$ \\
\hline 50 million to 99.999 million & $\begin{array}{c}57 \\
N=61\end{array}$ & $\begin{array}{c}60 \\
N=62\end{array}$ & $\begin{array}{c}44 \\
N=62\end{array}$ \\
\hline 100 million to 199.999 million & $\begin{array}{c}65 \\
N=17\end{array}$ & $\begin{array}{c}53 \\
N=17\end{array}$ & $\begin{array}{c}56 \\
N=16\end{array}$ \\
\hline 200 million or more & $\begin{array}{c}71 \\
N=17\end{array}$ & $\begin{array}{c}88 \\
N=17\end{array}$ & $\begin{array}{c}88 \\
N=17\end{array}$ \\
\hline
\end{tabular}

* Logit and order of least square estimates were calculated on asset size. At least one of the two tests was found positive and significant at the 0.05 level.

$\mathbf{N}=$ number of total usable responses in each cell

Table 6

Responses from Banks, by Percentage of Assets in Commercial and Industrial Loans

\begin{tabular}{cccc}
\hline \hline $\begin{array}{c}\text { Bank Assets in } \\
\text { Commercial and } \\
\text { Industrial Loans } \\
\text { (percent) }\end{array}$ & $\begin{array}{c}\text { Clients Contacted } \\
\text { Banks for Help to } \\
\text { Locate Equity Monies* } \\
\text { (percent) }\end{array}$ & $\begin{array}{c}\text { Banks Aware } \\
\text { of Potential } \\
\text { Equity Investors* } \\
\text { (percent) }\end{array}$ & $\begin{array}{c}\text { Banks Referred } \\
\text { Clients to } \\
\text { Equity Investors* } \\
\text { (percent) }\end{array}$ \\
\hline 0 to 9.9 & $\begin{array}{c}36 \\
\mathrm{~N}=67\end{array}$ & $\begin{array}{c}44 \\
\mathrm{~N}=68\end{array}$ & $\begin{array}{c}19 \\
\mathrm{~N}=68\end{array}$ \\
10 to 19.9 & 56 & 47 & 43 \\
$\mathrm{~N}=62$ & $\mathrm{~N}=62$ & $\mathrm{~N}=60$ \\
20 or more & 69 & 72 & 59 \\
$\mathrm{~N}=29$ & $\mathrm{~N}=29$ & $\mathrm{~N}=29$ \\
\hline \hline
\end{tabular}

- Logit and order of least square estimates were calculated on the percentage of bank assets in commercial and industrial loans. At least one of the two tests was found to be significant to the 0.05 level.

$\mathbf{N}=$ number of total usable responses in each cell

percentages of their portfolios in commercial and industrial loans were more aware of potential equity investors $(\$ 100,000$ or more). Only 44 percent of the banks with less than 10 percent of their assets in business loans were aware of equity or venture investors. In contrast, 72 percent of the banks with at least 20 percent of their assets in commercial and industrial loans knew of such investors.
Table 6 also shows that banks with higher percentages of their assets in business loans were more likely to refer their clients to equity investors. Only 19 percent of the banks with less than 10 percent of their assets in business loans linked clients with equity suppliers. In sharp contrast, 59 percent of the banks with at least 20 percent of their assets in business loans introduced clients to equity 
investors. These figures suggest that banks with a strong business orientation, as measured by the percentage of assets in commercial and industrial loans, were more active in equity capital markets.

It is worth noting that there was a relatively weak correlation between the levels of bank assets and the percentage of investments in commercial and industrial loans. The commitment of a bank to the commercial and industrial sector was not necessarily dependent on size.

\section{Conclusions}

Several conclusions may be drawn from the study:

1. Local information networking is a crucial factor in the flow of venture capital.

2. The knowledge of bankers of venture capital markets is one of the most important variables facilitating venture capital flow.

3. Non-metropolitan banks are less involved in facilitating the flow of equity capital than are metropolitan banks. Individuals with the potential for firm start-up or expansion are limited in non-metropolitan regions because of inadequate information.

4. Larger banks are more aware of equity suppliers and are more active than smaller banks in introducing equity-seeking clients to potential investors.

5. Banks with higher percentages of assets in commercial and industrial loans are more likely to be involved in facilitating the flow of equity capital than those with less commercial and business loan activity.

6. Bankers who are unaware of equity capital markets may seriously limit their regions in achieving their economic potential, especially in high growth industries.

\section{Policy Recommendations}

It is clear from the results of this study that banks are in a position to play important roles in transmitting critical information between entrepreneurs and venture capitalists. It is evident that there is substantial variation in how this function is performed. To improve this aspect of capital markets, public policymakers may wish to intervene. Some suggested strategies follow.

1. Banking associations should be encouraged to educate their members about the importance of equity and venture capital markets in stimulat- ing local economic development. Information about how equity markets function and the changing nature of these markets should be relayed to bankers.

2. University extension services, regional planning commissions, and other organizations might be encouraged to play significant roles in facilitating the linkage between bankers and equity suppliers.

3. State governments should facilitate information exchanges between debt and equity capital suppliers and private businesses.

4. Information alone is not adequate in facilitating venture investments. The issue of trust seems implicit in most venture capital referrals. Venture capitalists rely on bankers or other trusted individuals who understand the special needs of both entrepreneurs and capitalists. The personal contacts of debt and equity suppliers are important. Further research regarding the importance of trust in information exchanges would be useful.

\section{References}

Combs, Robert P., Glen C. Pulver, and Ron E. Shaffer. Financing New Small Business Enterprise In Wisconsin. R3198. Madison, Wisc.: Research Division of the College of Agricultural and Life Sciences, University of Wisconsin-Madison, 1983.

Dominguez, John R. Venture Capital. Lexington, Massachusetts: D. C. Heath and Company, 1974.

Greene, Michael. "No Seeds, No Trees: A Profile of Seed Capital Funds." The Entrepreneurial Economy. (February 1985). 6-12.

Hustedde, Ronald J. Venture Capital Market Barriers In Wisconsin: Perceptions of Venture Capitalists. Unpublished Master's Thesis. Madison, Wisc.: University of Wisconsin-Madison, 1987.

Mikesell, James, and Steve Davidson. "Financing Rural America." Rural Financial Markets: Research Issues for the 1980s. Chicago, Ill.: Federal Reserve Bank of Chicago, Public Information Center, 1982.

Morris, Jane Koloski, ed. Venture Capital Journal. Wellesley Hills, Massachusetts: Venture Economics, Inc., May 1986. Venture Capital Journal. Wellesley Hills, Massachusetts: Venture Economics, Inc., June 1986.

New York Times. February 6, 1987. 1, 31.

Pratt, Stanley E., ed. Pratt's Guide to Venture Capital Sources. Wellesley Hills, Massachusetts: Venture Economics, Inc., 1984.

Premus, Robert. Venture Capital and Innovation. Washington, D.C.: Joint Economic Committee, Congress of the United States, U.S. Printing Office, 1985. 
Pulver, Glen C. Community Economic Development Strategies. Madison, Wisc.: University of Wisconsin Extension, 1986.

Silver, A. David. Up Front Financing. New York: John Wiley \& Sons, Inc., 1982.
Wade, Randall, and Frank Place. Entrepreneurial Culture In Wisconsin. Technical Report 85-1. Madison, Wisc.: State of Wisconsin Department of Development, November 1985. 